\title{
Use of radioisotopes in the study of textile workers with byssinosis and chronic lung damage
}

\author{
L. S. VASKOV \\ Radioisotope Laboratory, Research Institute of Labour Safety, Sofia, Bulgaria
}

\begin{abstract}
Vaskov, L. S. (1973). British Journal of Industrial Medicine, 30, 37-41. Use of radioisotopes in the study of textile workers with byssinosis and chronic lung damage. A radioisotope method of measuring separately the circulation times for the pulmonary artery and pulmonary veins is described. Combined with pulmonary scintigraphy this method has been used to invesigate textile workers with lung changes.

In the workers with no evidence of heart failure there was a prolongation of the pulmonary artery circulation time but no change in the pulmonary venous circulation time. In workers with signs of right heart failure there was a prolongation of right heart filling time as well as pulmonary artery circulation time but still no prolongation of the pulmonary venous circulation time. In this group the cardiac stroke volume was reduced but the output was maintained by a tachycardia. In spite of the prolonged pulmonary circulation time there was a reduction in pulmonary blood volume and poor perfusion on the scintigram.
\end{abstract}

The use of radioisotopes in circulation studies can be applied to the clinical diagnosis of pulmonary disease (Johnson, Lin, Akcay, and Taplin, 1964; Oriol, Anthonisen, and McGregor, 1968; Vaskov, 1970; Mihailov et al., 1970). Vascular lung scintigrams make it possible to show diffuse or localized areas where the circulation is disturbed (Taplin, Johnson, Dore, and Kaplan, 1964). Radioisotopes can now be used also to study the central haemodynamics in occupational lung diseases (Vaskov, 1966; 1970; 1972).

Two methods for determining the pulmonary artery circulation time separately from the pulmonary venous circulation time have been described already: (1) with a mixture of iodine-131 ( $\left.{ }^{131} I\right)$ and iodine-125 (Johnson et al., 1964), and (2) with ${ }^{131}$ I only (Vaskov, 1970). In this study the last method is applied to the clinical investigation of chronic lung disease in textile workers.

\section{Radiocardiography and radiocirculography}

The method is described diagrammatically in Figure 1. A bolus of radioactive material was injected into the right antecubital vein, and its passage first through the right heart and then through the left heart was picked up by counter I placed over the precordium. This records two peaks which represent the passage of the bolus through the right heart (R) and left heart (L) respectively. The time from injection (O) to the beginning of the ascent to $R$ is the peripheral venous time, the ascent to $R$ is the right heart filling time, and the distance between peaks $\mathbf{R}$ and $\mathbf{L}$ is the mean pulmonary circulation time (or central pulmonary circulation time). A pair of counters (II) were placed tangentially over the middle peripheral lung fields (left and right); these recorded the transit of radioindicator in the lung periphery or capillary bed. By arranging synchronous recording of these traces (see Fig. 2), it is possible to use the pulmonary peak (P) (Fig. 1) to divide the pulmonary circulation time into two-the arterial time ( $R$ to $P$ ) and the venous time 

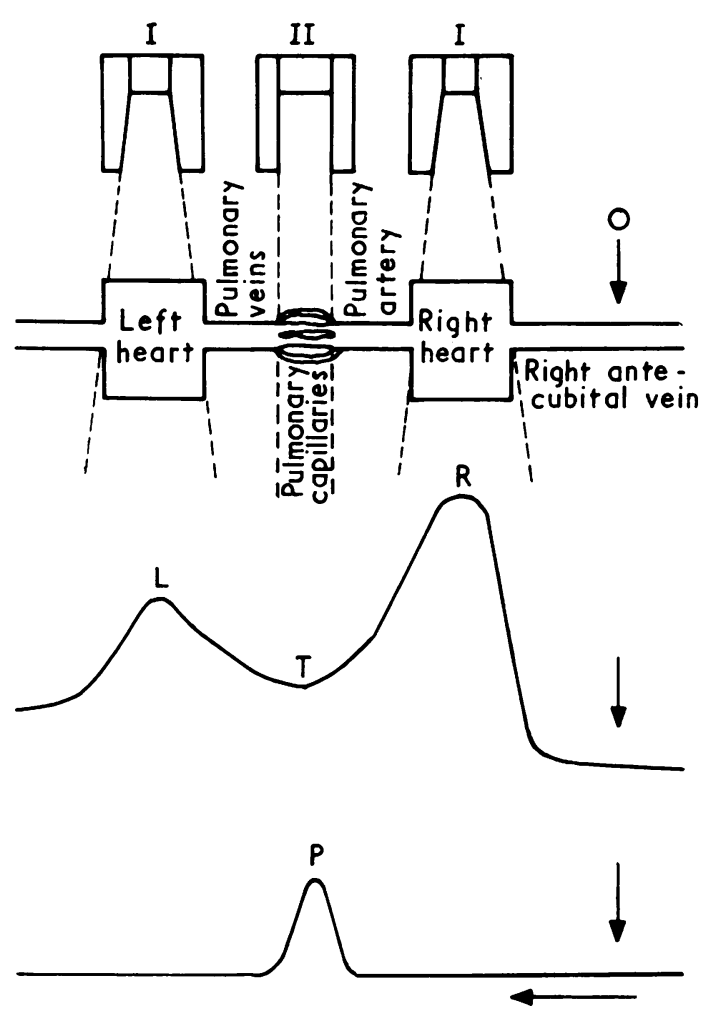

FIG. 1. Diagram of isotope studies on cardiac and pulmonary circulation (see text) (paper moves from left to right).

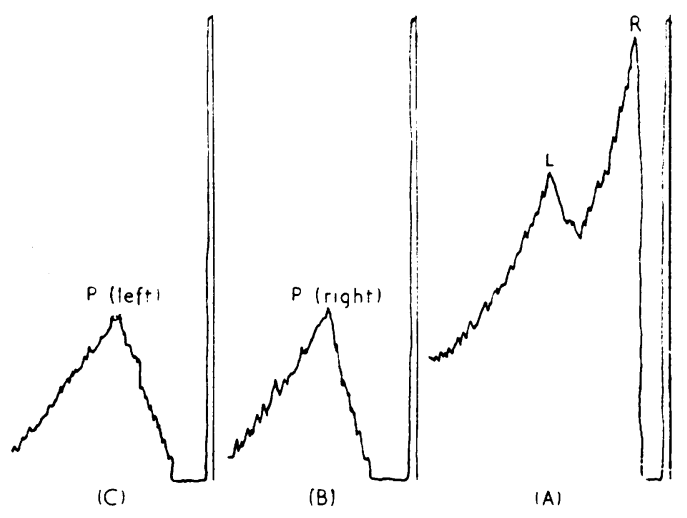

FIG. 2. Normal curves for cardiac and pulmonary circulation: (A) tracing from precordium showing right heart peak (R) and left heart peak (L) with intervening trough; (B) tracing from right lung periphery; (C) tracing from left lung periphery (paper moves from left to right).
( $P$ to $L)$. It is also possible to detect differences between the circulation in the two lungs by finding differences between the shapes of the two curves and the positions of the peaks.

A quantitative study of these curves makes possible the measurement of circulating blood volume, cardiac output and index, stroke volume and index, and blood volume in the lungs (Veall and Vetter, 1958; Mostbeck, 1963).

The radioisotope examination was carried out using a bolus of $50 \mu \mathrm{Ci}$ of human serum albumin (HSA) labelled with ${ }^{131} \mathrm{I}$. The radioactivity was recorded on a four-channel Radiocirculograph EFKI (Hungaria) or Nukleopan 3 T (Siemens): speed 150 respectively 120 $\mathrm{mm} / \mathrm{min}$, time-constant 0.2 or $0.3 \mathrm{sec}$ with integral or differential discrimination. Blood samples were compared with a standard in a well type scintillation counter.

Lung vascular scintigrams were carried out in 25 subjects including some from each group. Macroaggregated HSA ${ }^{131}$ I was used and the results were recorded with a SELO-D 2 Superscanner.

Population One hundred and two subjects were examined clinically from the following groups:

Group I Controls-35 healthy adults

Group II 28 textile workers with symptoms of chronic bronchitis but without evidence of right heart disease Group III 17 textile workers with chronic bronchitis, airways disease, and asthmatic symptoms but no signs of right heart disease

Group IV 22 textile workers with severe obstructive airways disease and chronic bronchitis, and signs of right-sided heart failure.

The percentage of women in all the groups was about $79 \%$ and of the smokers about $12 \%$. The diseases in $27.7 \%$ of examined textile workers in groups II, III, and IV are considered to be byssinosis. The dust conditions to which the textile workers were exposed at the time of the study were within the acceptable limits $\left(10 \mathrm{mg} / \mathrm{m}^{3}\right)$ but conditions for some may have been worse in the past.

Pulmonary function tests Standard ventilation and lung volume measurements were recorded for all subjects using a Spirograph Samargiev (Tiffeneau R. technics) and $\mathbf{N}_{2}$ method used by Ivanov and Tzolov (1960).

\section{Results}

The average age of the subjects in each group is shown in Table 1 with the length of occupational exposure to dust and the results of ventilation and lung volume studies. There was no significant difference between the mean ages of the groups. Those with occupational exposure (groups II, III, and IV) all showed evidence of airways obstruction and a relative increase in residual volume (RV). Only those in group IV showed a significant reduction in mean vital capacity.

The radioisotope circulation study results are given in Table 2.

There is no significant difference between the groups in circulating blood volume and cardiac index. The venous part of the central pulmonary 
TABLE 1

Age, Duration of Exposure, and Pulmonary Function Test Results

\begin{tabular}{|c|c|c|c|c|c|c|c|}
\hline \multirow[b]{2}{*}{ Group } & \multirow{2}{*}{$\begin{array}{l}\text { Age } \\
(y r)\end{array}$} & \multirow{2}{*}{$\begin{array}{c}\text { Duration } \\
\text { of } \\
\text { exposure } \\
(y r)\end{array}$} & \multicolumn{4}{|c|}{ Ventilation tests $(\%$ predicted $)$} & \multirow{2}{*}{$\begin{array}{c}R V / T L C \% \\
\quad(B T P S)\end{array}$} \\
\hline & & & $\begin{array}{l}V C \\
(m l)\end{array}$ & $\begin{array}{c}F E V_{(1 \cdot 0)} \\
(l .)\end{array}$ & $\begin{array}{c}F I V_{(1 \cdot 0)} \\
(l .)\end{array}$ & $\begin{array}{r}M V V \\
(l / m i n)\end{array}$ & \\
\hline $\begin{array}{r}\text { I } \\
\text { II } \\
\text { III } \\
\text { IV }\end{array}$ & $\begin{array}{l}40 \cdot 2 \\
44 \cdot 3 \\
39 \cdot 5 \\
48 \cdot 1\end{array}$ & $\begin{array}{c}0 \\
13 \cdot 1 \\
10 \cdot 2 \\
15 \cdot 0\end{array}$ & $\begin{array}{l}98 \cdot 3 \\
85 \cdot 1 \\
83 \cdot 6 \\
70 \cdot 7\end{array}$ & $\begin{array}{l}96 \cdot 7 \\
60 \cdot 2 \\
39 \cdot 5 \\
46 \cdot 3\end{array}$ & $\begin{array}{l}93 \cdot 9 \\
59 \cdot 2 \\
38 \cdot 1 \\
40 \cdot 1\end{array}$ & $\begin{array}{l}97 \cdot 1 \\
98 \cdot 4 \\
83 \cdot 9 \\
68 \cdot 0\end{array}$ & $\begin{array}{l}20 \cdot 2 \\
44 \cdot 7 \\
52 \cdot 8 \\
50 \cdot 7\end{array}$ \\
\hline
\end{tabular}

$\mathrm{VC}=$ vital capacity; $\mathrm{FEV}_{(1 \cdot 0)}=$ forced expiratory volume in one second; $\mathrm{FIV}_{(1 \cdot 0)}=$ forced inspiratory volume in one second; $M V V=$ maximum voluntary ventilation; $R V=$ residual volume; $T L C=$ total lung capacity.

circulation time is not increased even in those with evidence of right-sided heart failure (group IV). However, in the heart failure group (IV) the venous time (arm to heart- $\mathrm{O}$ to the beginning of the ascent of $\mathbf{R}$ in Fig. 1) and the right heart filling time are increased as well as the central pulmonary circulation time. There is also a significant fall in systolic index, and the cardiac output is maintained by the rise in cardiac rate. In spite of the increase in pulmonary circulation time, which is all in the arterial part ( $R$ to $P$ in Fig. 1), there is a significant fall in the volume of blood in the lungs. This finding must be taken in conjunction with the marked increase in relative residual volume (RV/TLC, Table 1) and is supported by a reduction in peripheral lung perfusion as recorded by scintigrams.

Group II workers, who showed moderately severe airways obstruction (Table 1) with a relative increase in residual volume, did not show any significant circulatory disturbance by the dynamic isotope methods. Group III, with a more marked disturbance of ventilation and residual volume but no evidence of right heart failure, did show an increase in pulmonary circulation time due to an increase in the arterial time only. The other results were not significantly different from those of the controls.

Examples of the curves are given in Figures 3 and 4. The curves from a subject in group III are shown in Figure 3. There is a prolongation of central pulmonary circulation time due to an increase in pulmonary artery circulation time ( $R$ to $P$ ). In this patient the two peaks $R$ and $L$ recorded by the precordial counter are quite distinct. In eight of the subjects in group IV there was a fusion of the right and left heart curves with the loss of a distinct $L$ peak. An example is given in Figure 4.

The pulmonary scintigrams carried out on the control group (I) were all normal (see Fig. 5). However, abnormal scintigrams were recorded in two out of seven examined subjects in group II, in two out of four in group III, and in four out of six in group IV. While some showed a symmetrical

TABLE 2

Radioisotope Circulation Study Results

(Averages for each group)

\begin{tabular}{|c|c|c|c|c|c|c|c|c|c|}
\hline \multirow[b]{2}{*}{ Group } & \multirow{2}{*}{$\begin{array}{l}\text { Venous } \\
\text { time } \\
(\mathrm{sec})\end{array}$} & \multirow[b]{2}{*}{$\begin{array}{c}R . \text { heart } \\
\text { filling } \\
\text { time } \\
(\mathrm{sec})\end{array}$} & \multicolumn{3}{|c|}{ Circulation times (sec) } & \multirow{2}{*}{$\begin{array}{c}\text { Circulation } \\
\text { blood } \\
\text { vol. } \\
\left(\mathrm{ml} / \mathrm{m}^{2}\right)\end{array}$} & \multirow{2}{*}{$\begin{array}{c}\text { Cardiac } \\
\text { index } \\
\left(\mathrm{l} / \mathrm{min} / \mathrm{m}^{2}\right)\end{array}$} & \multirow{2}{*}{$\begin{array}{c}\text { Stroke } \\
\text { index } \\
\left(\mathrm{ml} / \mathrm{m}^{2}\right)\end{array}$} & \multirow{2}{*}{$\begin{array}{c}\text { Blood } \\
\text { volume } \\
\text { in } \\
\text { lungs } \\
\left(\mathrm{ml} / \mathrm{m}^{2}\right)\end{array}$} \\
\hline & & & $\begin{array}{c}\text { Central } \\
\text { pulmonary } \\
(R \text { to } L)\end{array}$ & $\begin{array}{c}\text { Pulmonary } \\
\text { artery } \\
(R \text { to } P)\end{array}$ & $\begin{array}{c}\text { Pulmonary } \\
\text { veins } \\
(P \text { to } L)\end{array}$ & & & & \\
\hline $\begin{array}{r}\text { I } \\
\text { II } \\
\text { III } \\
\text { IV }\end{array}$ & $\begin{array}{l}2 \cdot 49 \\
3 \cdot 06 \\
2 \cdot 94 \\
4.81\end{array}$ & $\begin{array}{l}2 \cdot 53 \\
2 \cdot 58 \\
2 \cdot 88 \\
3.50\end{array}$ & $\begin{array}{l}6.63 \\
7.07 \\
7.63 \\
7.74 \\
\end{array}$ & $\begin{array}{l}3 \cdot 33 \\
4 \cdot 32 \\
4 \cdot 60 \\
4.74\end{array}$ & $\begin{array}{l}3 \cdot 30 \\
2 \cdot 75 \\
3 \cdot 03 \\
3 \cdot 00\end{array}$ & $\begin{array}{l}2598 \\
2912 \\
2891 \\
3009\end{array}$ & $\begin{array}{l}3 \cdot 71 \\
3 \cdot 80 \\
3 \cdot 63 \\
3 \cdot 06\end{array}$ & $\begin{array}{l}49 \cdot 1 \\
51 \cdot 6 \\
50 \cdot 3 \\
31.3\end{array}$ & $\begin{array}{l}352 \\
316 \cdot 2 \\
383 \cdot 2 \\
242\end{array}$ \\
\hline
\end{tabular}

The values in bold type are significantly different (at the $5 \%$ level) from the corresponding values for the control group. Mean heart rate: group I, 75.5 beats/min; group IV, $97 \cdot 8$ beats/min. 


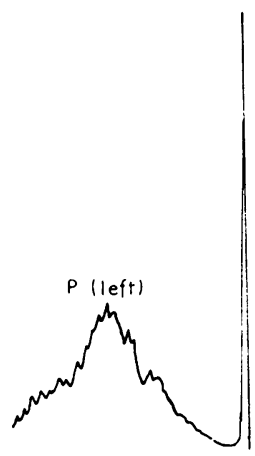

(C)

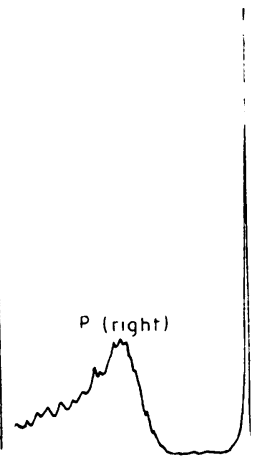

(B)

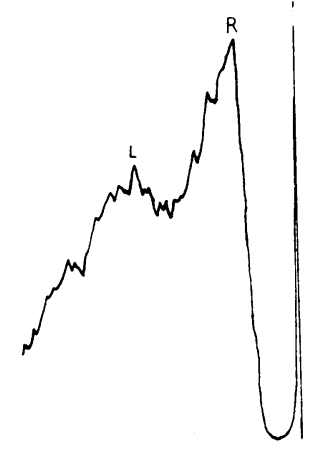

(A)

FIG. 3. Curves similar to those shown in Fig. 2 but from a subject with airways disease (group III). They show more slope in the ascent to $R$, a less marked trough, and then a less well defined peak $L$. Note difference between pulmonary curves (B and $C$ ).

circulatory loss, others showed focal areas of loss often corresponding to focal areas of emphysema (Fig. 6).

\section{Discussion}

Radioisotope studies on these groups of textile workers, when compared with the pulmonary function tests, both confirmed and extended the findings of conventional tests. The circulatory measurements showed clear-cut abnormalities in most of the severely affected subjects, especially if they were in right heart failure. The most constant finding was an increase in pulmonary artery circulation time, that is the time interval between the first (R) peak recorded over the heart and the peak recorded over the lung periphery. In spite of this prolonged time the total pulmonary blood volume was reduced rather than increased and the cardiac output was normal. Thus it may be concluded that the slowing of this part of the circulation is due to narrowing of the blood vessels and/or actual loss of vessels. The reduced perfusion in the pulmonary scintigrams is consistent with either explanation.

In the most seriously affected group (IV) there was a delay in transit time from arm to heart and a delay in filling of the right heart. Although the stroke volume was reduced the cardiac output was maintained by a compensatory increase in heart rate. There was a further change which was not measured numerically but could be observed from the shape of the curves. In many of the group IV patients the right and left heart curves fused so that the left peak was lost. This indicates a degree of overlap between the filling and emptying of the bolus in the two ventricles, which suggests that the ventricles were overfilled and their emptying was slow. This phenomenon is confined to the heart failure group; it has been observed in other types of heart failure (Mihailov et al., 1970; Vaskov, 1966, 1970) and is attributed to myocardial failure and a marked disturbance of central pulmonary haemodynamics.

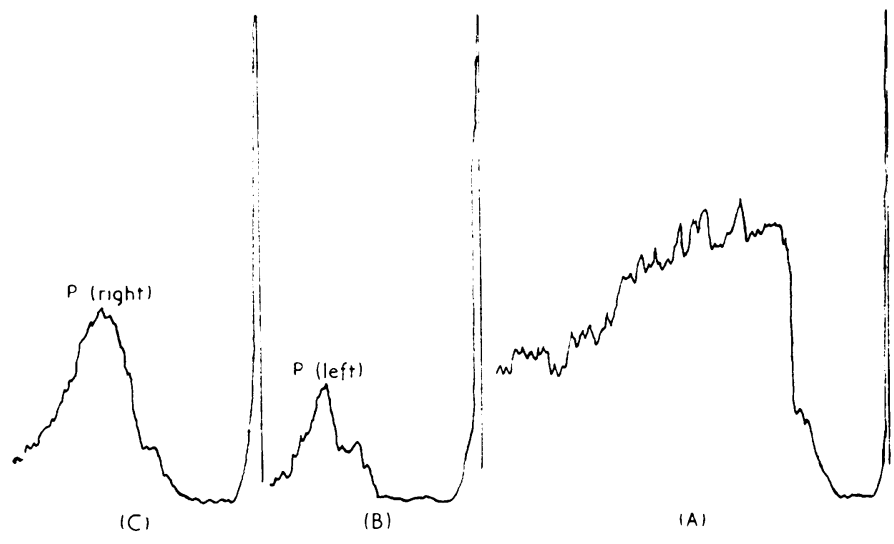

FIG. 4. Grossly abnormal curves from subject in group IV with right heart failure. Note the slope of ascent and fusion of the two cardiac curves (A) and inequality of the right and left pulmonary curves (B and $C$ ). 


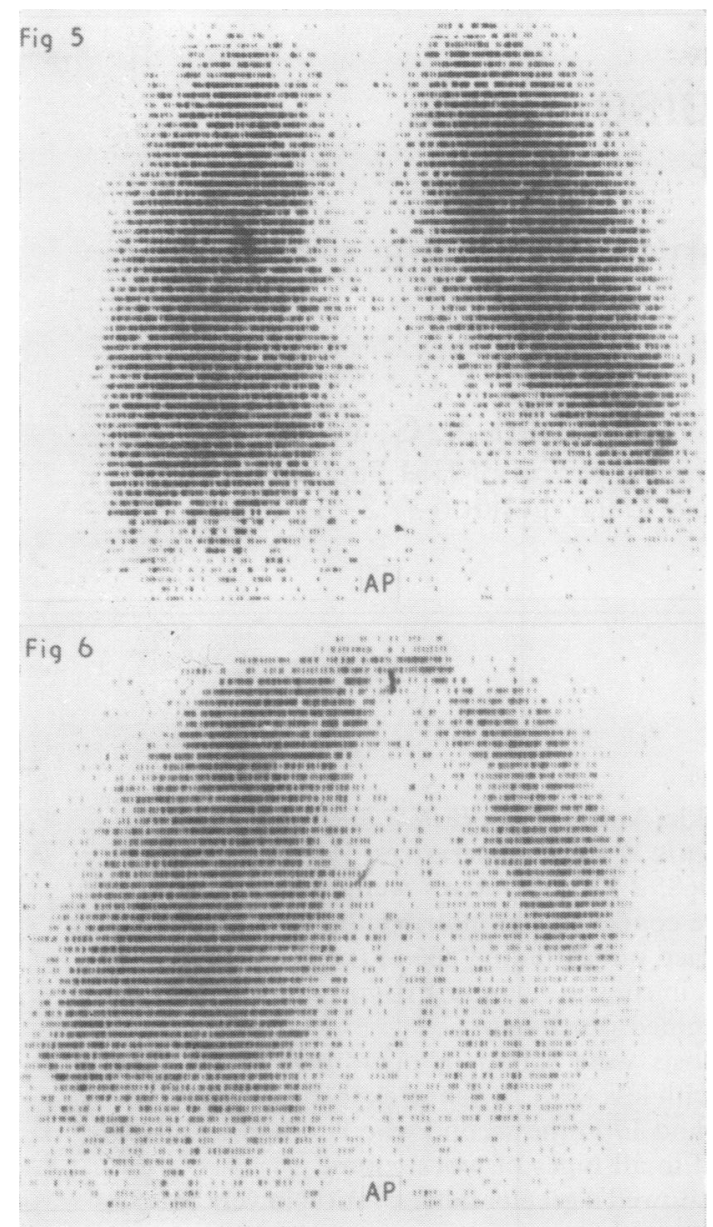

FIG. 5. Normal scintigram from subject in control group $\mathrm{I}$.

FIG. 6. Scintigram from subject with airways obstruction (group III) and emphysema. Marked loss of circulation to the left lung with some additional focal loss on both sides is seen.

Scintigraphy revealed abnormalities in a proportion of all the disabled workers showing either a general reduction or a localized loss or both. Taken in conjunction with the other findings this could help to explain the mechanism of the circulatory disturbance in many cases.

\section{References}

Ivanov, I., and Tzolov, H. (1960). Funktionalno isledvane na bolnite ot silicosa. M. i F., Sofia.

Johnson, L. E., Lin, C. K., Akcay, M. M., and Taplin, G. V. (1964). Radiopulmonary circulography for measurement of central mean transit time and its arterial and venous subdivisions. In: Dynamic Clinical Studies with Radioisotopes, pp. 249-66. U.S. Atomic Energy Commission, Springfield, Ill.

Mihailov, V., Vaskov, L., Mlachkov, C., Todorov, G., and Popitz, R. (1970). Radiocardiographic and radiocirculographic studies in persons with obstructive lung diseases. III. Congress of Bulgarian Radiologists. Varna, 1970.

Mostbeck, A. (1963). Die Bestimmung pulmonaler Kreislaufzeiten und des pulmonalen Blut-Volumens mit $\mathrm{J}^{\mathbf{1 3 1}}$ Albumin. Cardiologia, 43, 225-238.

Oriol, A., Anthonisen, N., and McGregor, M. (1968). Limitations of indicator dilution methods in estimation of cardiac output in chronic lung disease. American Heart Journal, 75, 589-595.

Sova, J., Ježek, V., and Kolár, M. (1963). Radiocardiography and pulmonary radiocirculography using $\mathbf{I}^{131}$-albumin in cardiopathies, Cardiologia, 43, 13-30.

Struchkov, V. I., Modestov, V. K., Kaperko, F. F., Dolina, O. A., Shtengold, E. S., and Meshine, E. N. (1966). Evaluation of the cardiovascular function in patients with pulmonary involvement (in Russian; Eng. summary). Grudnaya khirurgiya, 8, no. 1, 47-51.

Swyngedauw, J., Warembourg, H., Swyngedauw, J., Delomez, M., and Bonningue, N. (1965). Le Gammaangiocardiogramme. Journal de Radiologie, 46, 607-624.

Taplin, G. V., Johnson, D. E., Dore, E. K., and Kaplan, H. S. (1964). Organ visualization by photoscanning using micro- and macro-aggregates of radioalbumin. In Medical Radioisotope Scanning, vol. 2, pp. 3-31. International Atomic Energy Agency, Vienna.

Vaskov, L. (1966). Kolichestvena radiokardiographia. Vatreshni bolesti (Sofia), pt. 4, 497-503.

(1970). Gammaradiocardiografia, radiopulmocircolografia in alcune malattie polmonari professionali. Medicina del Lavoro, 61, 483-490.

(1972). Kolichestvena radiocardiographia pri njakoi professionalni belodrobni bolesti. Vatreshni bolesti (Sofia), pt. 1, 35-38.

Veall, N., and Vetter, H. (1958). Radioisotope Techniques in Clinical Research and Diagnosis. Butterworth, London.

Received for publication October 11, 1971. 